\title{
INTRUSIVE EQUIVALENTS OF FLOOD VOLCANICS: EVIDENCE FROM PETROLOGY OF XENOLITHS IN QUATERNARY TANA BASANITES
}

\author{
Dereje Ayalew ${ }^{1}$, Gezahegn Yirgu ${ }^{1}$, Endale Ketefo ${ }^{1}$, P. Barbey ${ }^{2}$ and J. Ludden ${ }^{2}$ \\ ${ }^{1}$ Department of Geology and Geophysics, Faculty of Science, Addis A baba University \\ PO Box 1176, Addis Ababa, Ethiopia, e-mail: dereayal@geol.aau.edu.et \\ ${ }^{2}$ CRPG-CNRS, B.P. 20, 54501 Vandoeuvre Les Nancy, France
}

\begin{abstract}
The Injibara Quaternary basanites enclose a variety of xenoliths spanning in composition from peridotite through pyroxenite and gabbro to granite. This study focuses on the pyroxenite, gabbro and granite xenoliths. The pyroxenite xenoliths (enstatite + diopside + olivine \pm spinel \pm plagioclase \pm ilmenite \pm paragasite) are diverse, including olivine-orthopyroxenite, olivineclinopyroxenite and websterite. They represent a suite of crystal cumulates from basalts with tholeiitic affinity evolving by polybaric crystal fractionation processes, or alternatively they may be related to chemical diversification of parental magma. The gabbro xenoliths, containing widely varying modal proportions of plagioclase, augite, enstatite, olivine and ilmenite, appear to be fragments of cumulate plutonic rocks, fractionated from tholeiitic basalts at high-level. They often show reaction textures, with a vermicular intergrowth of smaller augite, plagioclase and a chemically complex opaque phase composition embedded in glass from orthopyroxene. The granitic xenoliths contain quartz and two distinct feldspars-a sodic plagioclase and a potassic alkali feldspar- coprecipitated from the melt; accompanying mafic minerals are hydrous biotite and muscovite. This suggests that such granite magmas crystallized under water-saturated condition $\left(\mathrm{P}_{\mathrm{H} 2 \mathrm{O}}=5 \mathrm{kbar}\right)$.
\end{abstract}

Key words/phrases: Cumulate, Ethiopia, Injibara, tholeiitc basalt, xenolith

\section{INTRODUCTION}

In intra-continental plate-tectonic setting, ultramafic xenoliths are frequently found in alkali basalts (e.g., Menzies, 1983), believed to have somewhat a deeper origin in the upper mantle. The ultramafic xenoliths are thought to represent the solid residue from the partial fusion event generating the magma containing them. Thus, they provide direct information on the composition, structure and physical properties of upper mantle involved in the generation of the magma hosting them. The hosting basalts appear to have risen relatively rapidly to the surface without undergoing significant fractional crystallization and/or crustal contamination.

Within the Ethiopian volcanic province, mantle xenoliths are common in the Quaternary alkali volcanic fields (Ottonello et al., 1978; Morten et al., 1992; Bedini et al., 1997; Roger et al., 1997; 1999; Conticelli et al., 1999), although they are also recorded in nephelinitic flows interbedded within Oligocene flood basalts (Roger et al., 1997; 1999) and in alkali basalts from shield volcano (Bastien, 2001). The ultramafic xenoliths have variable sizes reaching up to $25 \mathrm{~cm}$ in diameter and are mineralogically heterogeneous, showing a variety of compositions including lherzolite, hazburgite, dunite and rare websterite. They show different textures (granuloblastic, protogranular and porphyroclastic) and have undergone to some extent deformation followed by a later partial recrystallization. Comparison of peridotite xenolith suites from different localities reveals systematic differences suggestive of regional mantle heterogeneities.

Petrologic and geochemical studies (Roger et al., 1999) of peridotite xenoliths in Injibara region reveal that the lithospheric mantle underneath (i) has become refractory (depleted in $\mathrm{Rb}, \mathrm{Ba}, \mathrm{Th}, \mathrm{U}$, $\mathrm{Nb}$, Ta and LREE) as a result of previous partial melting episodes, probably associated with the pan-African orogenesis event, (ii) subsequently, is slightly re-enriched (enriched in $\mathrm{Ba}, \mathrm{U}$ and $\mathrm{La}$, without significant HFSE negative anomaly) by a metasomatic process, possibly related to the ascent of the Oligocene Afar plume, (iii) is $690 \mathrm{Ma}$ old, an age similar to that of the East African Orogen (e.g., Stern, 1994) and (iv) deviates to higher temperatures with respect to the continental geotherm.

The Ethiopian dome has been undergoing complex tectonic, magmatic and uplift activities since early Oligocene, although the chronology of these events is still debated. The study of mantle and crust xenoliths may help to constrain the 
possible evolution of these events. Previous studies have focused mainly on peridotite xenoliths (Roger et al., 1997; 1999; Conticelli et al., 1999). In this study mineralogical compositions are presented for pyroxenite, gabbro and granite xenoliths entrained in Quaternary intraplate alkali basalts near Injibara. The main objective of this study is to assess the petrologic features of the xenoliths in an attempt to relate with the flood basalt volcanism.

\section{GEOLOGIC BACKGROUND}

The Ethio-Yemeni volcanic province provides a classic example of continental rifting preceeded by the impingment of a mantle plume. Volcanism began in the Oligocene with the emplacement of a massive flood basalt pile and continued to the present day in the Red Sea and Gulf of Aden oceanic spreading centers and the east African continental rift (Hofmann et al., 1997). In the northwest Ethiopian plateau, the volcanic succession erupted onto the Mesozoic sedimentary rocks, which in turn covered the late Proterozoic pan-African island arc crust. The volcanic succession consists of a thick (up to $2500 \mathrm{~m}$ ), distinctly bimodal, sequence of basalts and rhyolite ignimbrites underlying low angle shield volcanoes (Termaber formation). Quaternary alkali basalts (Tana lava) occur locally related to local rift structures, north-south trending extensional faults (Chorowicz et al., 1994). Volcanic plugs of trachytic composition are conspicuous in the region surrounding lake Tana and they penetrate flows of the overlying shield volcanoes (Dercq et al., 2001).

The region south of Lake Tana (Fig. 1) exposes Quaternary volcanic rocks composed of vesicular alkali basalts and cinder cones, indicating the volatile rich nature of the host magma. The host lavas are basanitic in composition and are dated at $0.39 \pm 0.03 \mathrm{Ma}\left({ }^{40} \mathrm{Ar} /{ }^{39} \mathrm{Ar}\right.$ dating, Hofmann, 1997). The basanites occur as massive, vesicular and fragmented rocks. They are aphyric to sparsely porphyritic containing phenocrysts, in order of decreasing abundance, of olivine, plagioclase, clinopyroxene and occasionally nepheline set in a fine-grained matrix composed of the same phases as the phenocryst assemblage (Begosew Abate et al., 1998). Geochemical studies of basanites, particularly ${ }^{3} \mathrm{He} /{ }^{4} \mathrm{He}$ isotopic ratios (Marty et al., 1996), show wide variation ranging from 0.33 to 9.9 $\mathrm{Ra}$, attesting to the involvement of depleted asthenosphere-like mantle source $\left({ }^{3} \mathrm{He} /{ }^{4} \mathrm{He}\right.$ ratios nearly constant at about $8 \pm 1 \mathrm{Ra}$ ) in their origin. However, the extremely low ${ }^{3} \mathrm{He} /{ }^{4} \mathrm{He}$ ratios are thought to represent crustal contamination, given the young age of these lavas. Conticelli et al. (1999) proposed that the basanites were generated by moderate degrees of partial melting of depleted lithospheric lherzolite and subsequently, have undergone olivine fractionation en route to the surface.

\section{PETROGRAPHY}

The Injibara basanites contain a variety of xenoliths spanning in composition from peridotite through pyroxenite and gabbro to granite (Table 1). Detailed petrologic and geochemical features of the peridotite xenoliths are given elsewhere (Roger et al., 1997; 1999; Conticelli et al., 1999) and are thus omitted from this study.

\section{Pyroxenite}

There is marked variations in the modal compositions of the pyroxenite xenoliths which are of olivine-orthopyroxenite (I6), olivine-clinopyroxenite (IC) and websterite (IE). Both olivineorthopyroxenite and websterite contain spinel (up to $3 \%$ ). In addition, olivine-orthopyroxenite contains rare amphibole crystals, often surrounded by opaque reaction rims/resorbition. Olivineclinopyroxenite contains small amounts of plagioclase $(\sim 2 \%)$ and ilmenite $(\sim 3 \%)$. The pyroxenite xenoliths possess inequigranular texture made up of smaller olivine (0.1 to $0.5 \mathrm{~mm}$ ), somewhat larger clinopyroxene $(0.1$ to $1 \mathrm{~mm})$ and still larger orthopyroxene (1 to $4 \mathrm{~mm}$ ). Spinel occurs frequently as vermicular grain $(0.1-2 \mathrm{~mm}$ in size) or as tiny inclusion within orthopyroxenes. The pyroxenite xenoliths do not display any anisotropic fabric such as lineation and foliation, and exhibit granular texture. Pyroxene grains in the olivine-orthopyroxenite are often strained and show frequently numerous ductile flow features such as kink bands and mechanical twinning. These features suggest that they were emplaced during an episode of tectonic activity affecting the mantle. They also display numerous exsolution features (e.g., orthopyroxene exsolves lamellae of clinopyroxene). Reaction textures (sponge-like circular aggregates) are observed in both olivineorthopyroxenite and websterite, which are thought to develop as a result of spinel-pyroxene breakdown reactions. Similarly, olivine-clinopyroxenite shows a reaction texture formed in response to pyroxene-plagioclase unstable relationships. 


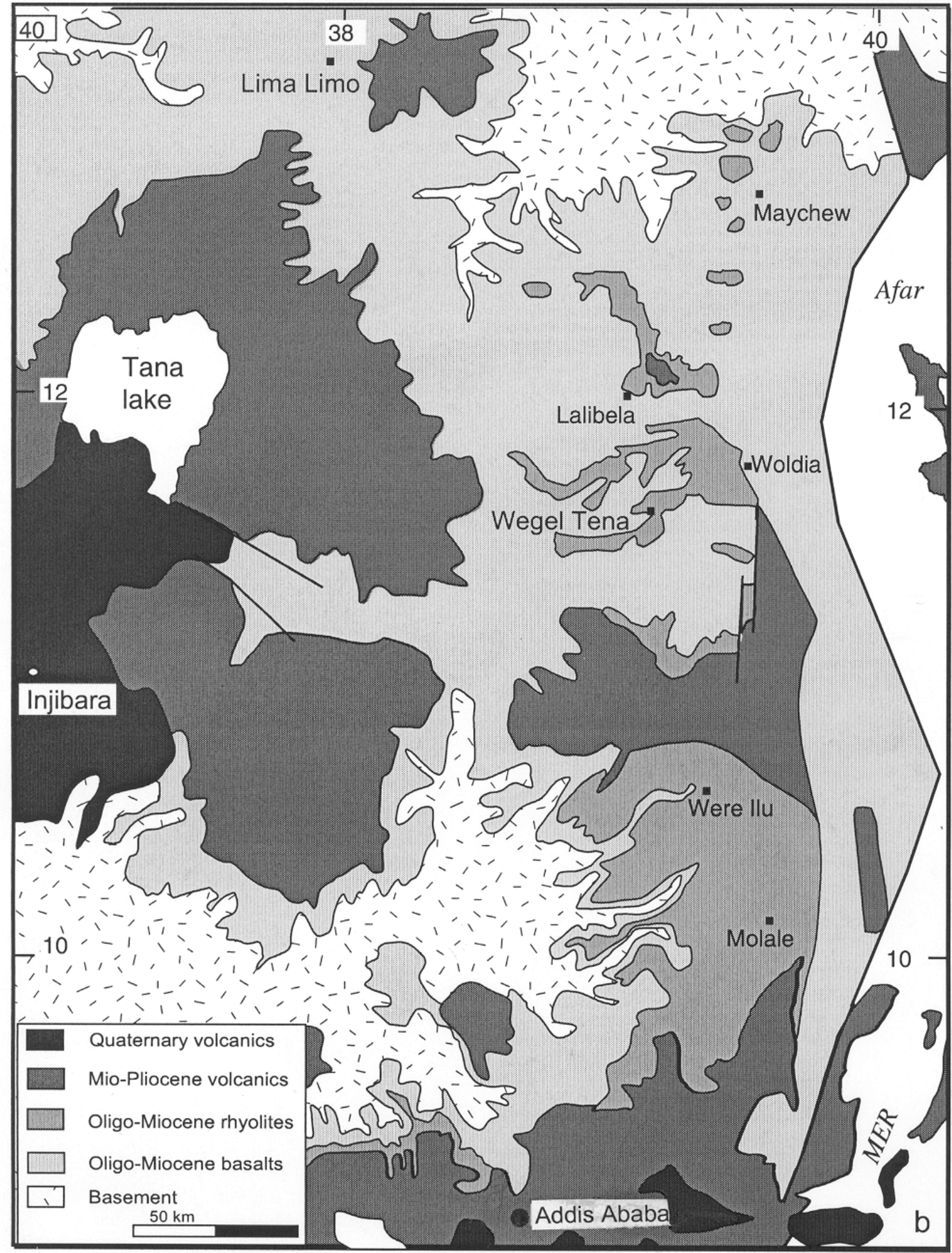

Fig. 1. Geological map of the northern Ethiopian province, showing the distribution of the different types of volcanic rocks (after Merla et al., 1979). 
Table 1. Abundances of modal mineralogy (Le Maitre, 1989) in xenoliths from Injibara basanites.

\begin{tabular}{|c|c|c|c|c|c|c|c|}
\hline & \multicolumn{3}{|c|}{ Pyroxenite } & \multicolumn{2}{|c|}{ Gabbro } & \multicolumn{2}{|c|}{ Granite } \\
\hline & I6 & IC & IE & ID & IF & IB & IA \\
\hline Olivine & 9 & 20 & 2 & 2 & 2 & & \\
\hline Orthopyroxene & 81 & 5 & 77 & 5 & 2 & & \\
\hline Clinopyroxene & 6 & 70 & 20 & 15 & 5 & & \\
\hline Spinel & 3 & & 1 & & & & \\
\hline Ilmenite & $<1$ & 3 & & 3 & 1 & & \\
\hline Amphibole & & & & & & & \\
\hline Plagioclase & & 2 & & 75 & 90 & 20 & 5 \\
\hline K-feldspar & & & & & & 5 & 80 \\
\hline Quartz & & & & & & 50 & 15 \\
\hline Biotite & & & & & & 5 & \\
\hline Muscovite & & & & & & 20 & \\
\hline
\end{tabular}

Note: The modal composition or mode was determined by point-counting technique (about 2500 points per thin section).

\section{Gabbro}

The gabbroic xenoliths consist of varying proportions of plagioclase (75-90\%), clinopyroxene (5-15\%), orthopyroxene $(\sim 3 \%)$, olivine $(\sim 2 \%)$ and ilmenite $(1-3 \%)$, an identical mineral assemblage, with the exception of orthopyroxene, to that observed as a phenocryst phase in the erupted basanites. The gabbroic xenoliths vary in diameter between 2 and $5 \mathrm{~cm}$ and posses generally granular texture comprising of small polygonal crystals with quite homogeneous size $(\leq 1 \mathrm{~mm})$. They often show reaction textures, which occur in aggregates of rounded domains with irregular outlines of about 2 to $3 \mathrm{~mm}$ in diameter, composed of minute skeletal crystals of augite, plagioclase and opaque phase embedded in an interstitial glass. This is thought to relate to partial melting of ancient orthopyroxene, which is preserved as pseudomophs, and provides a direct petrographic evidence for partial melting.

\section{Granite}

The felsic xenoliths consist largely of two alkali feldspars (an albite-rich and an orthoclase-rich, the former being less abundant than the latter) and quartz, with subordinate amounts of muscovite and biotite. They have mineralogical composition of alkali feldspar granite (IA) and monzogranite (IB) and are hereafter referred to as granites for simplicity. The occurrence of peraluminous minerals such as muscovite and biotite clearly denotes peraluminous granite (S-type granites). These xenoliths exhibit granular texture consisting of coarse, more or less polygonal crystals. The granites show numerous perthitic texture of plagioclase in K-feldspar. They display myrmekitic texture, which suggests subsolidus unmixing of K- bearing plagioclase in a ternary system open to excess Si (Castle and Lindsley, 1993).

\section{MINERALOGY}

\section{Pyroxenes}

Both clino and orthopyroxenes from the pyroxenites (IE and I6) and gabbros (ID and IF) are analysed (Table 2 and Fig. 2). Orthopyroxene consists of enstatite displaying a very restricted range of chemical composition. The enstatites are more Mg-rich in the pyroxenite specimens compared to that of gabbro xenoliths $\left(\mathrm{En}_{84-87} \mathrm{~V}\right.$.

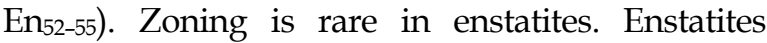
show a remarkably narrow range of $\mathrm{Mg}$ values $\left[\right.$ hereafter $\left.\mathrm{Mg} \#=100 \mathrm{Mg} /\left(\mathrm{Mg}+\mathrm{Fe}^{2+}\right)\right]$ within each suite, varying from 85 to 88 in pyroxenites and from 54 to 57 in gabbros. $\mathrm{Al}_{2} \mathrm{O}_{3}$ content is high in pyroxenites (4.7-5.3\%), whereas it is much lower in gabbros (1.6 to 1.8\%). Enstatites of gabbro have augitic rims, comparable in composition to augite from reaction texture. This can be explained by a vermicular intergrowth of smaller less-Al augite, more calcic plagioclase and unknown $\mathrm{Fe}, \mathrm{Mg}$ opaque phase containing $\mathrm{Si}$ formula around orthopyroxene grain boundaries.

Clinopyroxene is diopsidic in composition in the pyroxenite xenoliths. Diopsides of pyroxenites have restricted $\mathrm{Mg \#}$ in the range 86-89. The composition of phenocryst and microphenocrysts is remarkably similar. Diopiside commonly shows exsolution feature, in which augite occurs as minute exsolved plates. $\mathrm{Al}_{2} \mathrm{O}_{3}$ contents are high and show narrow range (6.9-8.6\%). Diopsides of nearly all pyroxenites are characterized by enrichment of $\mathrm{Na}\left(0.5-2.1 \% \mathrm{Na}_{2} \mathrm{O}\right)$, which may be a consequence of metasomatic enrichment. 
Table 2. Representative compositions of pyroxene from Injibara xenoliths.

\begin{tabular}{|c|c|c|c|c|c|c|c|c|c|c|c|c|}
\hline \multirow[b]{3}{*}{ Sample } & \multicolumn{5}{|c|}{ Orthopyroxene } & \multicolumn{7}{|c|}{ Clinopyroxene } \\
\hline & \multicolumn{2}{|c|}{ Pyroxenite } & \multicolumn{3}{|c|}{ Gabbro } & \multirow[b]{2}{*}{ Sample } & \multicolumn{3}{|c|}{ Pyroxenite } & \multicolumn{3}{|c|}{ Gabbro } \\
\hline & IE & $\mathrm{I} 6$ & $\mathrm{ID}_{\mathrm{C}}$ & $\mathrm{ID}_{\mathrm{R}}$ & ID & & $\mathrm{IE}_{\mathrm{M}}$ & $\mathrm{I} 6_{\mathrm{E}}$ & $\mathrm{I} 6_{\mathrm{I}}$ & ID & $\mathrm{ID}_{\mathrm{Rx}}$ & IF \\
\hline $\mathrm{SiO}_{2}$ & 53.9 & 53.5 & 51.1 & 53.9 & 50.1 & $\mathrm{SiO}_{2}$ & 51.38 & 49.91 & 49.54 & 50.84 & 50.24 & 48.98 \\
\hline $\mathrm{Al}_{2} \mathrm{O}_{3}$ & 5.2 & 4.9 & 1.7 & 0.9 & 1.6 & $\mathrm{Al}_{2} \mathrm{O}_{3}$ & 6.93 & 8.40 & 8.38 & 3.48 & 1.55 & 6.65 \\
\hline $\mathrm{TiO}_{2}$ & 0.119 & 0.384 & 0.157 & 0.484 & 0.145 & $\mathrm{TiO}_{2}$ & 0.58 & 1.64 & 1.50 & 0.31 & 0.89 & 0.81 \\
\hline $\mathrm{FeO}$ & 7.8 & 9.5 & 26.2 & 15.4 & 27.6 & $\mathrm{FeO}$ & 3.30 & 4.22 & 4.13 & 11.58 & 15.58 & 9.72 \\
\hline $\mathrm{MnO}$ & 0.187 & 0.059 & 0.429 & 0.349 & 0.357 & $\mathrm{MnO}$ & 0.046 & 0.094 & 0.144 & 0.209 & 0.459 & 0.167 \\
\hline $\mathrm{MgO}$ & 31.2 & 30.8 & 19.5 & 13.5 & 18.1 & $\mathrm{MgO}$ & 14.28 & 13.70 & 13.52 & 12.19 & 14.07 & 11.74 \\
\hline $\mathrm{CaO}$ & 0.65 & 0.55 & 1.00 & 14.75 & 1.00 & $\mathrm{CaO}$ & 20.42 & 19.77 & 20.32 & 20.41 & 15.39 & 20.32 \\
\hline $\mathrm{Cr}_{2} \mathrm{O}_{3}$ & 0.65 & 0.09 & 0.01 & 0.09 & 0.00 & $\mathrm{Cr}_{2} \mathrm{O}_{3}$ & 1.22 & 0.23 & 0.23 & 0.00 & 0.13 & 0.02 \\
\hline $\mathrm{Na}_{2} \mathrm{O}$ & 0.027 & 0.125 & 0.003 & 1.016 & 0.073 & $\mathrm{NiO}$ & 0.002 & 0.083 & 0.158 & 0.002 & 0.030 & 0.002 \\
\hline \multirow[t]{2}{*}{ Total } & 99.7 & 99.9 & 100.0 & 100.5 & 99.0 & $\mathrm{Na}_{2} \mathrm{O}$ & 1.54 & 1.81 & 1.81 & 0.71 & 0.23 & 1.31 \\
\hline & & & & & & $\mathrm{K}_{2} \mathrm{O}$ & 0.020 & 0.001 & 0.001 & 0.001 & 0.001 & 0.001 \\
\hline $\mathrm{Si}$ & 1.8818 & 1.8702 & 1.9341 & 2.0126 & 1.9325 & Total & 99.72 & 99.85 & 99.73 & 99.73 & 98.56 & 99.72 \\
\hline $\mathrm{Al}^{\mathrm{IV}}$ & 0.1182 & 0.1298 & 0.0659 & 0.0000 & 0.0675 & & & & & & & \\
\hline $\mathrm{Al}^{\mathrm{VI}}$ & 0.0946 & 0.0719 & 0.0084 & 0.0415 & 0.0065 & $\mathrm{Si}$ & 1.8697 & 1.8150 & 1.8040 & 1.9110 & 1.9292 & 1.8229 \\
\hline $\mathrm{Fe}^{3+}$ & 0.0012 & 0.0437 & 0.0494 & 0.0000 & 0.0581 & $\mathrm{Al}^{\mathrm{IV}}$ & 0.1303 & 0.1850 & 0.1960 & 0.0890 & 0.0702 & 0.1771 \\
\hline $\mathrm{Ti}$ & 0.0031 & 0.0101 & 0.0045 & 0.0136 & 0.0042 & $\mathrm{Al}^{\mathrm{VI}}$ & 0.1668 & 0.1750 & 0.1638 & 0.0653 & 0.0000 & 0.1144 \\
\hline $\mathrm{Cr}$ & 0.0179 & 0.0026 & 0.0002 & 0.0027 & 0.0000 & $\mathrm{Fe}^{3+}$ & 0.0063 & 0.0411 & 0.0715 & 0.0576 & 0.0331 & 0.1115 \\
\hline $\mathrm{Mg}$ & 1.6252 & 1.6042 & 1.0999 & 0.7532 & 1.0401 & $\mathrm{Ti}$ & 0.0158 & 0.0449 & 0.0410 & 0.0087 & 0.0256 & 0.0225 \\
\hline $\mathrm{Fe}^{2+}$ & 0.2261 & 0.2344 & 0.7808 & 0.4814 & 0.8325 & $\mathrm{Cr}$ & 0.0352 & 0.0067 & 0.0065 & 0.0001 & 0.0040 & 0.0006 \\
\hline $\mathrm{Mn}$ & 0.0055 & 0.0017 & 0.0138 & 0.0110 & 0.0117 & $\mathrm{Ni}$ & 0.0000 & 0.0024 & 0.0046 & 0.0000 & 0.0009 & 0.0000 \\
\hline $\mathrm{Ca}$ & 0.0244 & 0.0205 & 0.0405 & 0.5904 & 0.0413 & $\mathrm{Mg}$ & 0.7746 & 0.7427 & 0.7338 & 0.6826 & 0.8052 & 0.6509 \\
\hline \multirow[t]{2}{*}{$\mathrm{Na}$} & 0.0018 & 0.0085 & 0.0002 & 0.0736 & 0.0055 & $\mathrm{Fe}^{2+}$ & 0.0940 & 0.0867 & 0.0536 & 0.3057 & 0.4668 & 0.1900 \\
\hline & & & & & & $\mathrm{Mn}$ & 0.0014 & 0.0029 & 0.0045 & 0.0067 & 0.0149 & 0.0053 \\
\hline En & 86.34 & 84.23 & 55.43 & 41.02 & 52.44 & $\mathrm{Ca}$ & 0.7962 & 0.7701 & 0.7928 & 0.8218 & 0.6331 & 0.8103 \\
\hline Fs & 12.37 & 14.69 & 42.53 & 26.82 & 45.48 & $\mathrm{Na}$ & 0.1087 & 0.1275 & 0.1279 & 0.0514 & 0.0169 & 0.0944 \\
\hline \multirow[t]{4}{*}{ Wo } & 1.29 & 1.07 & 2.04 & 32.15 & 2.08 & K & 0.0009 & 0.0001 & 0.0001 & 0.0001 & 0.0001 & 0.0001 \\
\hline & & & & & & En & 46.31 & 45.19 & 44.31 & 36.42 & 41.23 & 36.82 \\
\hline & & & & & & Fs & 6.08 & 7.95 & 7.82 & 19.73 & 26.36 & 17.35 \\
\hline & & & & & & Wo & 47.61 & 46.86 & 47.87 & 43.85 & 32.41 & 45.83 \\
\hline
\end{tabular}

Note: Mineral compositions were determined by a CAMECA SX-50 electron microprobe at the University of Henri Poincaré, Nancy, France. Operating conditions were $15 \mathrm{kV}$ acceleration voltage, $10 \mathrm{nA}$ beam current, $1 \mathrm{vm}$ beam diameter and 320 s count times. C, core; R, rim; M, microphenocryst; E, exsolution; I, interstitial, Rx, reaction texture.

Most of the gabbroic clinopyroxenes also plot in the field of diopside, with few augite members. The clear difference is that the gabbroic clinopyroxenes contain less $\mathrm{Mg}$ like their respective orthopyroxenes. There are systematic differences in $\mathrm{Al}$ and Ti contents between the two gabbro specimens (samples ID and IF), with the former having higher $\mathrm{Al}\left(6.2-6.7\right.$ v. $\left.3.0-3.5 \% \mathrm{Al}_{2} \mathrm{O}_{3}\right)$ and $\mathrm{Ti}\left(0.7-0.8\right.$ v. $\left.0.3-0.4 \% \mathrm{TiO}_{2}\right)$. Granular augites from the partial melt texture are more enriched in $\mathrm{Fe}(15.6 \% \mathrm{FeO})$ and depleted in $\mathrm{Ca}(15 \% \mathrm{CaO})$ compared to the rest of augites (Fig. 2).

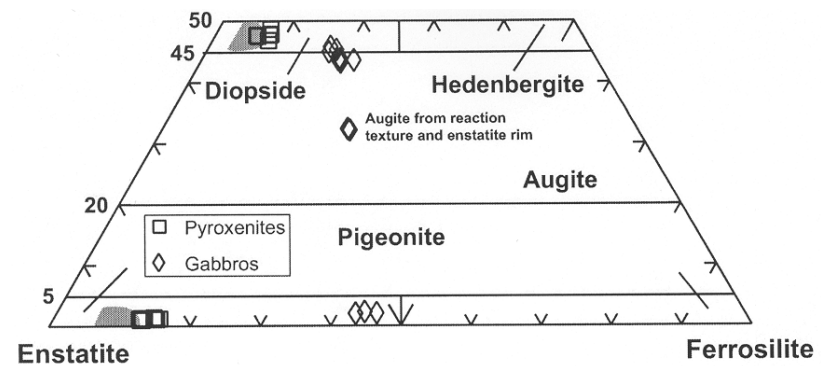

Fig. 2. The pyroxene quadrilateral, showing the compositional ranges for orthopyroxene and clinopyroxene in pyroxenite and gabbro of the Injibara xenoliths. Shown for comparison are pyroxenes in hazburgites (shaded field). Composition in mol per cent. 


\section{Oxides}

Spinel is a common Al-bearing accessory phase in pyroxenite xenoliths. Compositions of spinel phase (Table 3) are remarkably homogeneous within a single sample, but vary widely from one sample to another, with $\mathrm{Al}_{2} \mathrm{O}_{3}$ ranging from 43 to $62 \%$ and $\mathrm{Cr}_{2} \mathrm{O}_{3}$ from 4 to $22 \%$. Spinels depleted in $\mathrm{Cr}_{2} \mathrm{O}_{3}$ are confined to xenoliths with Al-rich pyroxene. Nomenclature of spinel in terms of plot of $\mathrm{Cr} /(\mathrm{Cr}+\mathrm{Al}$ ) ratios against $\mathrm{Mg \#}$ in spinel (Fig. 3) shows that they are of pleonaste type, with $\mathrm{Mg} / \mathrm{Fe}^{2+}$ ratios of 2.2-3.0. The $\mathrm{Cr}_{2} \mathrm{O}_{3}$ and $\mathrm{Al}_{2} \mathrm{O}_{3}$ contents of spinel are sensitive to the $\mathrm{fO}_{2}$ fluctuations (Hill and Roeder, 1974) and high $\mathrm{Cr}_{2} \mathrm{O}_{3}$ contents are consistent with reducing conditions during crystallization.

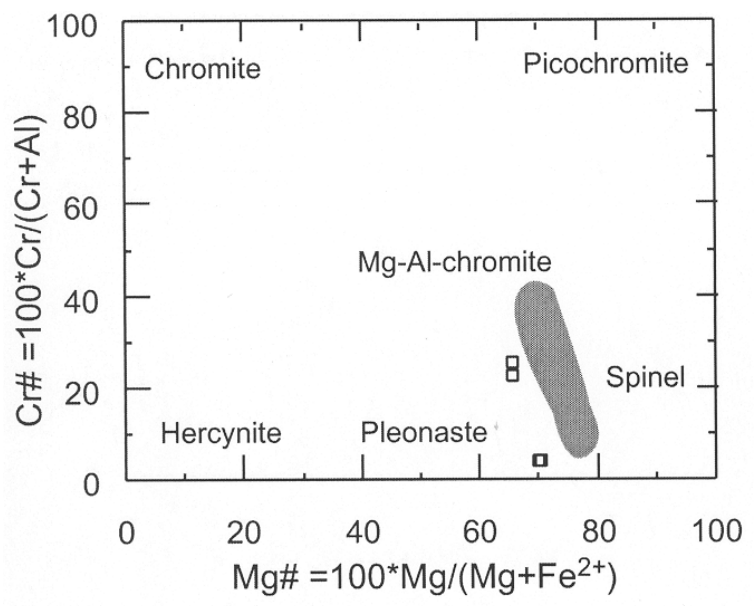

Fig. 3. Classification of spinel in terms of a plot of $\mathrm{Cr} /(\mathrm{Cr}+$ Al) ratios against $100 \mathrm{Mg} /\left(\mathrm{Mg}+\mathrm{Fe}^{2+}\right)$ ratios in spinels from pyroxenite xenoliths in Injibara basanite. Shown for comparison are spinels in hazburgites (shaded field).

Ilmenite, the normal Fe-Ti oxide phase, (Table 3) occurs rarely in the pyroxenite xenoliths being observed only in olivine-clinopyroxenite, but it is common in the gabbro xenoliths (up to 3\%).

\section{Feldspars}

Plagioclase is the dominant mineral in the gabbroic xenoliths, but occurs in trace amounts in the granitic xenoliths. Plagioclase composition (Table 4) in the gabbro xenoliths is remarkably constant and is uniformly orthoclase poor $\left(\mathrm{An}_{43-}\right.$ ${ }_{44} \mathrm{Or}_{<3}$ ). The An content in the gabbroic plagioclase is lower than $50 \%$, other mineralogical proportions tend towards a gabbroic composition, rather than diorite. Plagioclases become more sodic in granitic xenoliths $\left(\mathrm{An}_{15-34}\right)$.

$K$-feldspar is the most abundant constituent of granitic xenoliths, and is orthoclase $\left(\mathrm{Or}_{79-81}\right)$ and orthoclase perthite $\left(\mathrm{Or}_{67}\right)$ in composition (Table 4). The orthoclase contains small amounts of Cafeldspar $\left(A n_{<1}\right)$, while the orthoclase perthite contains relatively greater amounts of calcium $\left(A n_{7}\right)$, which is probably due to the presence of exsolution lamellae of plagioclase. Alkali feldspars that form myrmerkite texture have lower $\mathrm{K}$ component $\left(\mathrm{Or}_{60}\right)$, which is in a very good agreement with the observation of myrmerkite intergrowth.

\section{Hydrous minerals}

Amphibole is exceedingly rare, being observed only in olivine-orthopyroxenite, and displays a brown reaction aureole. The composition of amphibole (Table 5), expressed as numbers of (Na $+\mathrm{K})$ and $\mathrm{Si}$ atoms per formula unit, is paragasite with $(\mathrm{Na}+\mathrm{K})_{>0.5}$ and $\mathrm{Si}_{<6.5}$. It is thought to be a product of metasomatic origin, as indicated by $\mathrm{Na}$ enrichment of the associated clinopyroxene (up to $2.1 \% \mathrm{Na}_{2} \mathrm{O}$ ).

Biotite occurs only in the granite xenoliths. The $\mathrm{Fe} /(\mathrm{Fe}+\mathrm{Mg}$ ) ratio of biotites (Table 5) is 0.39-0.50, reflecting that the biotites tend to be more magnesium-rich. Mg-rich biotites from the more siliceous igneous rocks reflect constant or increasing $\mathrm{fO}_{2}$ conditions on the course of crystallization and cooling of magma (Wones and Eugster, 1965). A more magnesium-rich trend may represent saturation of the melt in regard to $\mathrm{H}_{2} \mathrm{O}$.

\section{Equilibrium conditions}

The mineral assemblage does not permit us to determine quantitatively the P-T of equilibration. The occurrence of spinel in olivine-orthopyroxenite and websterite corresponds to crystallization at high pressure, because of the increased solubility in basaltic liquid of $\mathrm{Cr}$ and $\mathrm{Fe}$ at high pressures (Hill and Roeder, 1974). The presence of plagioclase in gabbro constrains their depth of crystallization to less than about $30 \mathrm{~km}$, as plagioclase does not readily crystallize from basic melts at greater depths (Powell, 1978). The common occurrence of andesine plagioclase in the gabbro xenoliths may be ascribed to the product of low-pressure crystallization, as the An content of plagioclase increases with pressure. 
Table 3. Compositions of spinel and ilmenite.

\begin{tabular}{|c|c|c|c|c|c|c|c|c|}
\hline \multirow[b]{2}{*}{ Sample } & \multicolumn{4}{|c|}{ Spinel } & \multicolumn{2}{|c|}{ Ilmenite } & \multicolumn{2}{|c|}{ Opaques } \\
\hline & IE & IE & I6 & I6 & IC & ID & IC & ID \\
\hline $\mathrm{SiO}_{2}$ & 0.003 & 0.026 & 0.026 & 0.004 & 0.003 & 0.022 & 35.46 & 34.72 \\
\hline $\mathrm{Al}_{2} \mathrm{O}_{3}$ & 43.35 & 46.7 & 61.86 & 62.04 & 0.839 & 0.093 & 0.224 & 0.006 \\
\hline $\mathrm{TiO}_{2}$ & 0.199 & 0.214 & 0.153 & 0.238 & 53.09 & 53.36 & 0.047 & 0.126 \\
\hline $\mathrm{FeO}$ & 15.52 & 15.2 & 14.21 & 14.29 & 39.08 & 43.11 & 34.01 & 42.08 \\
\hline $\mathrm{MnO}$ & 0.074 & 0.14 & 0.126 & 0.002 & 0.276 & 0.751 & 0.976 & 0.774 \\
\hline $\mathrm{MgO}$ & 16.71 & 16.47 & 18.97 & 19.12 & 6.807 & 3.361 & 28.36 & 22.52 \\
\hline $\mathrm{CaO}$ & 0.002 & 0.002 & 0.002 & 0.002 & 0.046 & 0.047 & 0.331 & 0.296 \\
\hline $\mathrm{Cr}_{2} \mathrm{O}_{3}$ & 21.5 & 19.94 & 3.703 & 3.524 & 0.097 & 0.074 & 0.014 & 0.002 \\
\hline $\mathrm{NiO}$ & 0.355 & 0.088 & 0.319 & 0.114 & 0.264 & 0.001 & 0.097 & 0.192 \\
\hline $\mathrm{Na}_{2} \mathrm{O}$ & 0.003 & 0.003 & 0.003 & 0.005 & 0.061 & 0.004 & 0.02 & 0.016 \\
\hline $\mathrm{K}_{2} \mathrm{O}$ & 0.001 & 0.001 & 0.001 & 0.001 & 0.001 & 0.001 & 0.001 & 0.034 \\
\hline Total & 97.72 & 98.78 & 99.37 & 99.35 & 100.6 & 100.8 & 99.54 & 100.8 \\
\hline $\mathrm{Al}$ & 11.51 & 12.18 & 15.02 & 15.04 & 0.281 & 0.032 & 0.059 & 0.002 \\
\hline $\mathrm{Ti}$ & 0.034 & 0.036 & 0.024 & 0.037 & 11.35 & 11.73 & 0.008 & 0.022 \\
\hline $\mathrm{Fe}^{3+}$ & 0.772 & 0.335 & 0.492 & 0.485 & & & 0.228 & 0.118 \\
\hline $\mathrm{Cr}$ & 3.831 & 3.489 & 0.603 & 0.573 & 0.022 & 0.017 & 0.002 & $3 \mathrm{E}-04$ \\
\hline $\mathrm{V}$ & & & & & & & 0.703 & 0.859 \\
\hline $\mathrm{Fe}^{2+}$ & 2.154 & 2.478 & 1.957 & 1.975 & 9.29 & 10.54 & 6.105 & 7.942 \\
\hline $\mathrm{Mg}$ & 5.614 & 5.432 & 5.824 & 5.864 & 2.884 & 1.465 & 9.413 & 7.689 \\
\hline $\mathrm{Mn}$ & 0.014 & 0.026 & 0.022 & 3E-04 & 0.066 & 0.186 & 0.184 & 0.15 \\
\hline $\mathrm{Ni}$ & 0.064 & 0.016 & 0.053 & 0.019 & 0.06 & 3E-04 & 0.017 & 0.035 \\
\hline $\mathrm{Mg} \#$ & 0.657 & 0.659 & 0.704 & 0.705 & 0.237 & 0.122 & 0.598 & 0.488 \\
\hline $\mathrm{Cr} \#$ & 0.25 & 0.223 & 0.039 & 0.037 & 0.072 & 0.348 & 0.04 & 0.146 \\
\hline
\end{tabular}

$\mathrm{Mg} \#=\mathrm{Mg} /\left(\mathrm{Mg}+\mathrm{Fe}^{2+}\right) ; \mathrm{Cr} \#=\mathrm{Cr} /(\mathrm{Cr}+\mathrm{Al})$

Table 4. Feldspar analyses.

\begin{tabular}{|c|c|c|c|c|c|c|c|}
\hline \multirow[b]{2}{*}{ Sample } & \multicolumn{4}{|c|}{ Plagioclase } & \multicolumn{3}{|c|}{ Alkali feldspar } \\
\hline & $\mathrm{IF}_{\mathrm{M}}$ & IF & IB & IA & IA & IA $_{\text {Pert }}$ & IA \\
\hline $\mathrm{SiO}_{2}$ & 55.4 & 56.3 & 64.2 & 60.1 & 63.8 & 62.2 & 63.5 \\
\hline $\mathrm{Al}_{2} \mathrm{O}_{3}$ & 27.0 & 27.1 & 22.1 & 24.8 & 18.9 & 20.0 & 19.0 \\
\hline $\mathrm{FeO}$ & 0.322 & 0.171 & 0.126 & 0.002 & 0.025 & 0.002 & 0.021 \\
\hline $\mathrm{CaO}$ & 9.0 & 9.2 & 3.1 & 7.1 & 0.2 & 1.4 & 0.1 \\
\hline $\mathrm{Na}_{2} \mathrm{O}$ & 5.9 & 6.2 & 9.9 & 6.7 & 2.3 & 3.0 & 2.1 \\
\hline $\mathrm{K}_{2} \mathrm{O}$ & 0.5 & 0.5 & 0.1 & 1.6 & 13.4 & 11.6 & 13.9 \\
\hline Total & 98.1 & 99.5 & 99.6 & 100.2 & 98.6 & 98.2 & 98.6 \\
\hline $\mathrm{Si}$ & 2.537 & 2.547 & 2.843 & 2.684 & 2.968 & 2.899 & 2.961 \\
\hline $\mathrm{Al}$ & 1.458 & 1.443 & 1.153 & 1.303 & 1.035 & 1.096 & 1.044 \\
\hline $\mathrm{Fe}$ & 0.012 & 0.006 & 0.005 & 0.000 & 0.001 & 0.000 & 0.001 \\
\hline $\mathrm{Ca}$ & 0.444 & 0.446 & 0.149 & 0.340 & 0.010 & 0.069 & 0.004 \\
\hline $\mathrm{Na}$ & 0.528 & 0.542 & 0.849 & 0.577 & 0.208 & 0.273 & 0.187 \\
\hline K & 0.029 & 0.028 & 0.005 & 0.090 & 0.794 & 0.690 & 0.827 \\
\hline An & 44.4 & 43.9 & 14.8 & 33.8 & 0.9 & 6.7 & 0.4 \\
\hline $\mathrm{Ab}$ & 52.7 & 53.3 & 84.7 & 57.3 & 20.5 & 26.4 & 18.4 \\
\hline Or & 2.9 & 2.8 & 0.5 & 8.9 & 78.5 & 66.9 & 81.2 \\
\hline
\end{tabular}

M, microphenocryst; pert, pertite. 
Table 5. Compositions of amphibole and biotite.

\begin{tabular}{|c|c|c|c|c|c|c|}
\hline \multirow[b]{2}{*}{ Sample } & \multicolumn{2}{|c|}{ Amphibole } & \multirow[b]{2}{*}{ Sample } & \multicolumn{3}{|c|}{ Biotite } \\
\hline & I6 & I6 & & IB & IB & IB \\
\hline $\mathrm{SiO}_{2}$ & 42.0 & 45.1 & $\mathrm{SiO}_{2}$ & 35.8 & 34.0 & 38.0 \\
\hline $\mathrm{Al}_{2} \mathrm{O}_{3}$ & 14.8 & 16.3 & $\mathrm{Al}_{2} \mathrm{O}_{3}$ & 14.3 & 15.2 & 15.9 \\
\hline $\mathrm{TiO}_{2}$ & 5.0 & 4.5 & $\mathrm{TiO}_{2}$ & 2.6 & 3.2 & 2.9 \\
\hline $\mathrm{FeO}$ & 6.4 & 3.9 & $\mathrm{FeO}$ & 13.8 & 17.3 & 13.6 \\
\hline $\mathrm{MnO}$ & 0.18 & 0.03 & $\mathrm{MnO}$ & 0.09 & 0.09 & 0.23 \\
\hline $\mathrm{MgO}$ & 15.6 & 11.7 & $\mathrm{MgO}$ & 11.1 & 9.8 & 11.9 \\
\hline $\mathrm{CaO}$ & 10.5 & 10.5 & $\mathrm{CaO}$ & 0.58 & 0.38 & 0.16 \\
\hline $\mathrm{Na}_{2} \mathrm{O}$ & 4.0 & 4.4 & $\mathrm{Na}_{2} \mathrm{O}$ & 0.44 & 0.05 & 0.07 \\
\hline $\mathrm{K}_{2} \mathrm{O}$ & 0.12 & 0.25 & $\mathrm{~K}_{2} \mathrm{O}$ & 7.5 & 7.1 & 8.6 \\
\hline Total & 98.6 & 96.8 & Total & 86.2 & 87.1 & 91.3 \\
\hline $\mathrm{Si}$ & 5.65 & 6.21 & $\mathrm{Si}$ & 5.84 & 5.59 & 5.82 \\
\hline $\mathrm{Al}^{\mathrm{IV}}$ & 2.35 & 1.79 & $\mathrm{Al}^{\mathrm{IV}}$ & 2.16 & 2.41 & 2.18 \\
\hline $\mathrm{Ti}$ & 8.00 & 8.00 & $\mathrm{Al}^{\mathrm{VI}}$ & 0.595 & 0.528 & 0.696 \\
\hline $\mathrm{Al}^{\mathrm{VI}}$ & 0.008 & 0.854 & $\mathrm{Fe}$ & 1.888 & 2.382 & 1.750 \\
\hline $\mathrm{Ti}$ & 0.503 & 0.462 & $\mathrm{Mg}$ & 2.698 & 2.404 & 2.724 \\
\hline $\mathrm{Mg}$ & 3.134 & 2.408 & $\mathrm{Mn}$ & 0.012 & 0.013 & 0.030 \\
\hline $\mathrm{Fe}$ & 0.772 & 0.492 & $\mathrm{Ti}$ & 0.317 & 0.398 & 0.329 \\
\hline $\mathrm{Mn}$ & 0.021 & 0.004 & $\mathrm{Ca}$ & 0.101 & 0.066 & 0.027 \\
\hline $\mathrm{Ca}$ & 1.514 & 1.544 & $\mathrm{Na}$ & 0.140 & 0.017 & 0.020 \\
\hline $\mathrm{Na}(\mathrm{M} 4)$ & 0.486 & 0.456 & K & 1.565 & 1.486 & 1.678 \\
\hline $\mathrm{Na}(\mathrm{A})$ & 0.548 & 0.728 & & & & \\
\hline $\mathrm{K}$ & 0.021 & 0.045 & & & & \\
\hline
\end{tabular}

\section{DISCUSSION}

The presence of exsolution lamellae in the pyroxene, composition variations (both mineral chemistry and mode) and lack of veins of pyroxenite in mantle peridotite all support the idea that the pyroxenite xenoliths represent a suite of crystal cumulates from basalts with tholeiitic affinity. Large variations in composition of spinel would be a consequence of element fractionation during crystallization. Moreover, spinels of pyroxenites are substantially enriched in ferric iron (up to $0.772 \mathrm{apfu}$ ), implying that they have been crystallized from a melt. The pyroxenite xenoliths are, therefore, unlikely to be the solid residue from the partial fusion event generating the alkali magma, which contains them. The variety of pyroxenites encountered can be explained by polybaric crystallization process (i.e., the aluminous phase changes from plagioclase to spinel pyroxenite with increasing pressure/depth), or alternatively they may be related to chemical diversification of parental magma.
A major problem with pyroxenite xenoliths involves what section of the lithosphere they actually represent. The presence of modal spinel in olivine-orthopyroxenite and websterite appear to indicate that these rocks have crystallized at high pressure, probably at the mantle-crust boundary. On the other hand, the occurrence of modal plagioclase in olivine-clinopyroxenites tend to favour that these xenoliths may represent lowpressure cumulates within the crust. It is possible that these different pyroxenites have been sampled by the ascending magma from various levels within the upper mantle and the crust.

The gabbroic xenoliths contain combination of the following minerals: plagioclase-clinopyroxeneorthopyroxene-olivine-ilmenite. Modal proportions of the above minerals vary widely, as might be expected in rocks of an essentially accumulative origin. The occurrence of orthopyroxene is inconsistent with an origin by crystal accumulation from fractionating alkali basalt. Since tholeiitic basalts are rare in the post-Oligocene period, it seems likely that the gabbroic xenoliths may represent cumulates from tholeiitic basalts erupted during the early volcanic phases, possibly the Oligocene tholeiitic flood basalts. Reaction textures between host basanite and gabbroic xenoliths have been observed. This indicates that the gabbro xenoliths have undergone partial melting during heating associated with adiabatic ascent of the host alkali magma.

There are a lot of gabbroic bodies in the lowgrade metamorphic belt of western Ethiopia under the volcanic cover (Teklewold Ayalew and Peccerillo, 1998). However, no metamorphic rocks associated with the Injibara xenoliths are present indicating that the gabbroic xenoliths do not belong to the Arabian-Nubian shield, but to the Ethiopian plateau-forming volcanics. The gabbroic xenoliths appear to be fragments of cumulate plutonic rocks, formed by accumulation of minerals as the basaltic magmas were held in crustal magma chambers.

The granite xenoliths contain quartz and two alkali feldspars (an albite-rich and an orthoclaserich) accompanied by subordinate amounts of muscovite and biotite. Hess (1989) showed that granitic rocks containing quartz and two alkali feldspars are formed from eutectic melt composition only at high water pressures $\left(\mathrm{PH}_{2} \mathrm{O}>4 \mathrm{~kb}\right)$. The 
presence of muscovite and biotite would require $\mathrm{H}_{2} \mathrm{O}$-rich magma at pressures $\left(\mathrm{P}_{\mathrm{H} 2 \mathrm{O}}=5 \mathrm{kbar}\right.$, Morse, 1970), suggesting that the granites were crystallized under water-saturated condition. Usually two-mica granites are described to be an Stype, which is derived by anatexes of sedimentary materials rich in aluminum (Barbarin, 1999). It should be emphasized that a eutectic melt may also be formed by crystal fractionation processes (e.g., Nédélec et al., 1995). A single Sr-Nd isotopic data from the granite xenoliths $\left({ }^{87} \mathrm{Sr} /{ }^{86} \mathrm{Sr}=\right.$ $0.703032 \pm 11$ with ${ }^{87} \mathrm{Rb} /{ }^{86} \mathrm{Sr}=0.0089$ and ${ }^{143} \mathrm{Nd} /{ }^{144} \mathrm{Nd}=0.512786 \pm 32$ with ${ }^{147} \mathrm{Sm} /{ }^{144} \mathrm{Nd}=$ 0.2265 ) is consistent with a depleted mantle origin without any significant crustal input. It is highly probable that these granite xenoliths are not anatectic liquids and that they were formed from the crystallization of more mafic magma.

Although the available data limit us to reconcile the genetic relationships, we prefer a model in which the pyroxenite, gabbro and granite xenoliths represent fractionated cumulates related to the Ethiopian flood tholeiitic basalt volcanism. Confirmation of this interpretation would require more detailed geochemical and isotopic data.

Fractionated cumulates and intrusions would cause underplating and thickening of the crust. Seismic data indicate a thickened crust $(\sim 40 \mathrm{~km})$ and the existence of high velocity $(\sim 7.4 \mathrm{~km} / \mathrm{s})$ lower crust beneath Ethiopian plateau (Ebinger and Casey, 2001). This is in good agreement with our results that imply important volumes of magma have been added to the crust as underplates or cumulates at the time of the emplacement of the flood basalts.

\section{CONCLUSIONS}

The pyroxenite xenoliths (olivine-orthopyroxenite, olivine-clinopyroxenite and websterite) are believed to represent a suite of crystal cumulates from basalts with tholeiitic affinity, evolved at different pressures, probably commencing in the crust/mantle boundary (i.e., the aluminous phase changes from spinel to plagioclase pyroxenite with decreasing pressure/depth), or alternatively they may be related to chemical diversification of parental magma.

The mineral assemblages involving plagioclase, olivine, clinopyroxene, orthopyroxene and ilmenite in gabbro xenoliths suggest the evolution of tholeiitic basaltic magmas fractionating at shallow depths. The gabbro xenoliths show reaction textures, where orthopyroxene grains are surrounded by a vermicular intergrowth of smaller augite, plagioclase and opaque phase, and interstitial glass.

The granite xenoliths are formed from eutectic melts crystallized at relatively high water pressures. The water content, required by muscovite and biotite to appear, increased by the crystallization of anhydrous phases and thus the granite liquids were formed from the crystallization of more mafic magmas.

\section{ACKNOWLEDGEMENTS}

The authors acknowledge grant from the French Ministry of Foreign Affairs (MAE) and the Institut National des Sciences de l'Univers (INSU-CNRS). Field work was supported by the Department of Geology and Geophysics of Addis Ababa University and the French Embassy in Addis Ababa. We thank C. Hannon for preparing thin sections and making microprobe analyses. We also thank the anonymous reviewers of SINET for their thorough review and constructive comments.

\section{REFERENCES}

1. Barbarin, B. (1999). A review of the relationships between granitoid types, their origins and their geodynamic environments. Lithos. 46:605-626.

2. Bastien, F. (2001). Etude pétrologique et géochimique des roches volcaniques basiques et enclaves de péridotites de la formation Termaber (Ethiopie). D.E.A. Université Joseph Fourier, Grenoble, France.

3. Bedini, R.M., Bodinier, J.L., Dautria, J.M. and Morten, L. (1997). Evolution of LILE-enriched small melt fractions in the lithospheric mantle: a case study from the east African rift. Earth Planet. Sci. Lett. 153:67-83.

4. Begosew Abate, Koeberl, C., Buchanan, P.C. and Körner, W. (1998). Petrography and geochemistry of basaltic and rhyodacitic rocks from lake Tana and the Gimjabet-Kosober areas (north central Ethiopia). J. Afr. Earth Sci. 26:119134.

5. Castle, R.O. and Lindsley, D.H. (1993). An exsolution silica-pump model for the origin of myrmekite. Contr. Mineral. Petrol. 115:58-65. 
6. Chorowicz, J., Collet, B., Bonavia, F.F., Mohr, P., Parrot, J.F. and Tesfaye Korme (1994). The Tana basin, Ethiopia: intraplateau uplift, rifting and subsidence. Tectonophysics 295:351-367.

7. Conticelli, S., Sintoni, M.F., Tsegaye Abebe, Mazzarini, F. and Manetti, P. (1999). Petrology and geochemistry of ultramafic xenoliths and host lavas from the Ethiopian volcanic province: an insight into the upper mantle under eastern Africa. Acta Vulcanol. 11:143-159.

8. Dercq, M., Arndt, N., Lapierre, H. and Gezahegn Yirgu (2001). Les pitons trachytiques d'Ethiopie ne sont pas les conduits d'alimentation des trapps. C. R. Acad. Sci. Paris. 332:609-615.

9. Ebinger, C. and Casey, M. (2001). Continental breakup in magmatic provinces: An Ethiopian example. Geology 29:527-530.

10. Hess, P.C. (1989). Origins of Igneous RocksHarvard, London, 336 pp.

11. Hill, R. and Roeder, P. (1974). Crystallization of spinel from basaltic liquid as a function of oxygene fugacity. J. Geol. 82:709-729.

12. Hofmann, C. (1997). Datation ${ }^{40} \mathrm{Ar} /{ }^{39} \mathrm{Ar}$ et paléomagnetism des trapps d'Ethiopie, du Deccan et de Sibérie. Ph.D. thesis, Univ. Paris VI-IPGP, France.

13. Hofmann, C., Courtillot, V., Féraud, G., Rochette, P., Gezahegn Yirgu, Endale Ketefo, and Pik, R. (1997). Timing of the Ethiopian flood basalt event and implications for plume birth and global change. Nature 389:838-841.

14. Le Maitre, R.W. (1989). A Classification of Igneous Rocks and Glossary of Terms. Blackwell, Oxford, 193 pp.

15. Marty, B., Pik, R. and Gezahegn Yirgu (1996). Helium isotopic variations in Ethiopian plume lavas: nature of magmatic sources and limit on lower mantle contribution. Earth Planet. Sci. Lett. 144:223-237.

16. Menzies, M.A. (1983). Mantle ultramafic xenoliths in alkaline magmas: evidence for mantle heterogeity modified by magmatic activity. In: Continental Basalts and Mantle Xenoliths, pp. 92-110, (Hawkesworth, C.J. and Norry, M.J., eds). Nantwich, Shiva.

17. Merla, G., Abbate, E., Azzaroli, A., Bruni, P., Canuti, P., Fazzuoli, M., Sagri, M. and Tacconi, P. (1979). A geological map of Ethiopia and Somalia (1973) and comment with a map of major landforms. C.N.R., Firenze, Italy.
18. Morse, S.A. (1970). Alkali feldspars with water at $5 \mathrm{~kb}$ pressure. J. Petrol. 11:221-253.

19. Morten, L., De Francesco, A.M., Bonavia F.F., Haileselassie, G., Bagossi, G.M. and Bondi, M. (1992). A new mantle xenolith locality from southern Ethiopia. Mineral. Mag. 56:422-425.

20. Nédélec, A., Stephens, W.E. and Fallick, A.E. (1995). The pan-African stratoid granites of Madagascar: alakaline magmatism in a post-collosional extensional setting. J. Petrol. 36:1367-1391.

21. Ottonello, G., Piccardo, G.B., Joron, J.L. and Treuil, M. (1978). Evolution of the upper mantle beneath the Assab region (Ethiopia): suggestion from petrology and geochemistry of ultramafic xenoliths and host basaltic lavas. Geol. Rundsch 67:547-576.

22. Powell, R. (1978). Crystallization conditions of lowpressure cumulate nodules from the Lesser Antilles island arc. Earth Planet. Sci. Lett. 39:162172.

23. Roger, S., Dautria, J.M., Coulon, C., Pik, R., Gezahegn Yirgu, Michard, A., Legros, P. and Dereje Ayalew (1999). An insight on the nature, composition and evolution of the lithospheric mantle beneath the north-western Ethiopian plateau: the ultrabasic xenoliths from the Tana lake province. Acta Volcanol. 11:161-168.

24. Roger, S., Pik, R., Dautria, J.M., Coulon, C., Gezahegn Yirgu, Dereje Ayalew and Legros, P. (1997). Rifting actif ou passif en Ethiopie? éléments de réponse apportés par l'étude des xénolites péridotitiques de la région du lac Tana. C.R. Acad. Sci. Paris. 324:1009-1016.

25. Stern, R.J. (1994). Arc assembly and continental collision in the Neoproterozoic east African orogen: implications for the consolidation of Gondwanaland. Ann. Rev. Earth Planet. Sci. 22:319351.

26. Teklewold Ayalew and Peccerillo, A. (1998). Petrology and geochemistry of the Gore-Gambella plutonic rocks: implications for magma genesis and the tectonic setting of the pan-African orogenic belt of western Ethiopia. J. Afr. Earth Sci. 27:397-416.

27. Wones, D.R. and Eugster, H.P. (1965). Stability of biotite: experiment, theory and application. Am. Mineral. 50:1228-1272. 